\title{
ANALYSIS OF «ON-FARM» LEVEL EFFICIENCY ON BROILER CHICKEN COMMODITY IN WEST JAVA
}

\author{
Wardhani Anggraita Dewi Kusuma*, Daryanto Arief, Djohar Setiadi \\ Department of Management and Business, Faculty of Business School, \\ Bogor Agricultural University, Indonesia \\ *E-mail: anggraitawardhani@gmail.com
}

\begin{abstract}
The rapid downstream industry with poultry consumption which is so large makes the upstream industries such as animal feed, breeding, and medicine in the country has a promising business opportunity for companies engaged in animal husbandry. However, in fact, people's breeding which is more numerous than large manufacturers are now starting to get rid of because they do not use modern technology and investment constraints. The purpose of this research is to analyze the technical efficiency of the broiler business and to identify the factors that influence the technical efficiency of broiler business in West Java province. To answer these problems, the researcher conducts a direct survey to the location of breeders and uses stochastic frontier analysis for data processing. The result of analysis by using Stochastic Frontier Cobb-Douglass regression method with decreasing of MLE function shows that some inputs which have real effects to broiler production are seed, feed, and also husk. Moreover, it is also seen that average mean efficiency of farmers in West Java is about 0.64 which means it is not efficient yet. It is also the impact of technical inefficiency factors such as age, education level, and breeding experience.
\end{abstract}

\section{KEY WORDS}

Technical efficiency, breeding, poultry, broiler, stochastic frontier.

The condition of the world economy is getting better from year to year in which it absolutely affects the pattern of public consumption. In addition, related to the matter of food, the parties concerned especially the government continues to strive to improve and to maximize in order that the food needs of the people are fulfilled.

The food field itself has different types and functions. As cited from one of Poultry Indonesia magazine article, the current world poultry consumption is expected to continue to grow in the future, and Asia, particularly Indonesia plays a big role in it, despite the weak economy will limit its growth. If broiler production is predicted to rise in most countries due to the increase of business in agriculture, weak economic growth in developed and developing countries could have an impact on limiting consumption increases. Factors that influence the growth of total poultry consumption are population change, household income growth; chicken prices are relatively cheaper than other meat, and changes in community lifestyle.

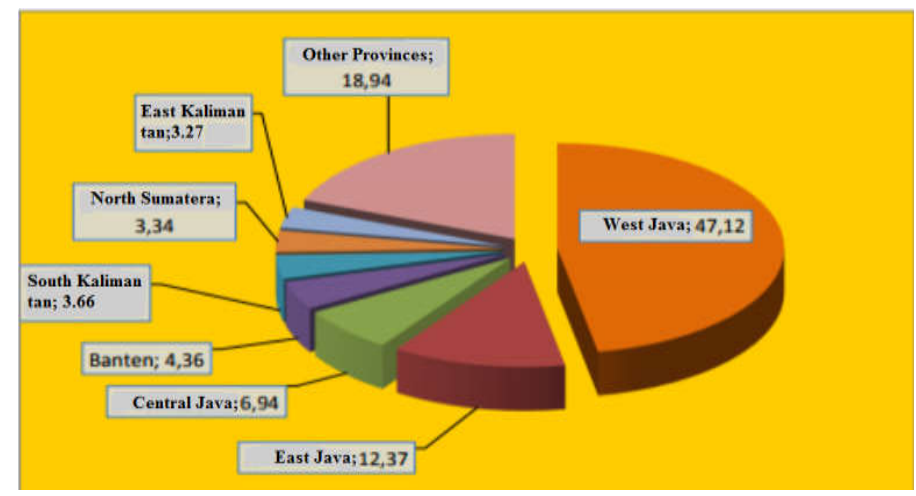

Figure 1 - Population Center of Broiler Chicken in Indonesia in 2011-2015 (Data Source: Center for Data and Information of Agriculture General Secretary of Ministry of Agriculture 2015) 
In Indonesia itself, according to the Center for Agricultural Data and Information System based on the average broiler population in the last five years (2011-2015) per province, the current national broiler population is dominated by seven central provinces among 34 provinces in Indonesia. The role of the seven provincial centers reaches $81.06 \%$ (1.09 billion of the national population) of the national broiler population, and is dominated by four provinces in Java contributing $70.78 \%$. The fourth covers the provinces of West Java, East Java, Central Java, and Banten with the contribution of respectively $47.12 \%, 12.37 \%$, $6.94 \%$, and $4.36 \%$. The next three provinces are from outside Java and its contribution, namely South Kalimantan (3.66\%), North Sumatra (3.34\%) and East Kalimantan (3.27\%).

Regarding to this matter, hence this research have some purposes that are (1) to describe performance and use of production input of broiler business in West Java province. (2) to analyze the technical efficiency of broiler business in West Java province. (3) to identify factors influencing technical efficiency of broiler business in West Java province. Hopefully, this research can also be useful especially (1) for the government to formulate policy materials in the development of broiler industry, especially by involving small-scale farmers. (2) for the livestock business community, this report can be used as a reference to optimize the performance of their business in order to achieve maximum results. (3) for students related to this activity, it can be used as a reference for doing further research and fostering entrepreneur interest especially for broiler commodity.

\section{METHODS OF RESEARCH}

Time and Place. This research is conducted in West Java Province by taking 3 points as sample so that this research is in accordance with the scope of the area that will be studied in Subang Regency, Tasikmalaya Regency, and Cimahi Regency. The study takes time for less than 11 months, beginning from April 2017 to May 2018.

Research Approach. The method used in this research is descriptive and analytical method with case study approach, (Crowe et al., 2011). Descriptive method is used to explain the interpretation of the results of the optimal technical efficiency calculation of livestock business on broiler commodities. The analytical method is used to analyze the efficiency calculation of broiler breeding business.

Data Collection Technique. This research uses primary and secondary data and information. Primary data are collected through survey method, recording, and direct interviews to respondents, companies involved as the core of small-scale chicken breeders, broiler breeders both members of the partnership (risk sharing and non-risk sharing) or independent. The data and information are collected using questionnaire instruments. Secondary data are collected through various documents from relevant agencies either collected directly or through internet network such as BPS, Directorate General of Animal Husbandry and Health, West Java Provincial Animal Husbandry Office, and relevant literatures on this research topic.

Data Analysis and Processing Technique. The problem in this research is how to measure the level of efficiency of broiler commodity supply chain in West Java. Meanwhile, to measure and make it efficient, it uses SFA or Stochastic Frontier Analysis method that employs the assumption of functional form for frontier (parametric), is stochastic and uses econometric methods, (Cullinane et al., 2006). Generally, the measurement of the efficiency level is done by dividing the total number of outputs by the total number of inputs. The calculation can be formulated as follows (Cullinane et al., 2006).

$$
\text { Efficiency }=\frac{\text { output }}{\text { Input }}
$$

Specifically, statistical analysis used to test the model of the production function and efficiency in this research uses stochastic frontier Cobb-Douglass production function, Zhuo et al (2015) are collected through structured questionnaires aiming to gather information 
about the input-output, prices of input-output, and socio-economic conditions of breeding businesses especially West Java.

The value of output is the value obtained from the production of broiler breeding. While the input consists of six input variables, namely: chicken seed (DOC), feed, vaccine, medicines and vitamins, gas and other heating devices, husk or other materials used as a cage base, (Castellini, 2002). The socio-economic conditions of some variables, including the age of the breeder, the length of the breeding experience, the period of production, the participation in partnership, and so forth.

Stochastic Frontier Production Function Analysis. The stochastic frontier Cobb-Douglas production function is used in the analysis of the production of broiler breeding in this study. The selection of the Cobb-Douglas production function as an approach is based on consideration that the form of the Cobb-Douglas production function can reduce the occurrence of multicollinearity, is homogeneous so that it can be used to decrease the dual cost function of the production function, its calculation is simple, can be made in the form of linear functions and most widely used in research, especially in agriculture, (Antras, 2004). The general form of the Cobb-Douglas production function model is as follows:

$$
Y=\beta_{0} X_{1}^{\beta 1} X_{2}^{\beta 2} X_{3}^{\beta 3} \ldots . . . X^{\beta n} e_{u}
$$

Where:

$Y=$ estimated quantity of production;

$\beta 0=$ intercept;

$\beta n=$ predictor parameter of $i$-th variable and is elasticity;

$\mathrm{Xi}=$ production factor used $(\mathrm{i}=1,2,3, \ldots, \mathrm{n})$;

$\mathrm{e}=$ natural number $(2,718)$;

$\mathrm{u}=$ error (disturbance term)

The estimation of the equation will be easier to do if the equation is converted to multiple linear form by renegotiating the equation. The logarithm of the above equation:

$$
\begin{gathered}
\log Y=\log \beta_{0}+\beta_{1} \log X_{1}+\quad \beta_{2} \log X_{2}+\beta_{3} \log X_{3}+\quad+\beta_{n} \log X_{n}+u \\
\quad \text { or } \\
\ln Y=\ln \beta_{0}+\beta_{1} \ln X_{1}+\beta_{2} \ln X_{2}+\beta_{3} \ln X_{3}+\ldots \ldots \ldots \ldots \ldots+{ }_{+} \beta_{n} \ln X_{n}+u
\end{gathered}
$$

Value of $\beta_{1}, \beta_{2}, \beta_{3}, \ldots . \beta_{\mathrm{n}}$ the Cobb-Douglas production function also shows the elasticity of $X$ to $Y$. The frontier production function is derived by connecting the maximum output points for each level of input use so that the production function represents the most efficient input-output combination and any point on the frontier production curve represents the condition for achieving technical efficiency in a breeding. Based on the concept, in the frontier production function, negative gap or no observation under the production function frontier is not permitted to occur.

At the same time, breeding that produces along the average production curve is not necessarily the most efficient because there is a possibility of a breeding business capable of producing above the curve or greater than the average production. If a breeding is at a point in the frontier production function, it means that it is technically efficient. If the production function of the frontier is known, then it can be estimated inefficiently by the actual position relative to the frontier, (Dolton et al., 2003).

Stochastic frontier production function produces two conditions simultaneously namely the factors that affect the efficiency and at the same time the inefficiency of breeders. The efficiency concepts of the input and output curves to be discussed in the integrated stochastic frontier production function require a function that is homogeneous (Greene, 2005). The production function that meets the criteria of homogeneity is the Cobb-Douglas production function because in Cobb-Douglas, the assumption constant return to scale is applied. In addition, this form of production function reduces the occurrence of 
heteroscedasticity and forms of Cobb-Douglas function is most widely used in research, especially field research of agriculture.

According to Kumbhakar and Lovell, (2003) The stochastic frontier production function is also called composed error model because it has two component error terms, which is caused by random effects ( $v i)$ and technical inefficiency $(u i)$, where $\varepsilon i=v i-u i$.

The form of stochastic frontier Cobb Douglas production function in poultry breeder and independent breeder is using the same model as following:

$$
\ln Y=\ln \beta_{0}+\beta_{1} \ln X_{1}+\beta_{2} \ln X_{2}+\beta_{3} \ln X_{3+} \beta_{4} \ln X_{4}+\beta_{5} \ln X_{5}+B_{6} X_{6} \ln \left(v_{i}-u_{i}\right)
$$

Where:

$\mathrm{Y}=$ Number of broiler production $(\mathrm{kg})$;

$\mathrm{X} 1$ = Chicken seeds;

$\mathrm{X} 2$ = Feed $(\mathrm{kg})$;

$\mathrm{X} 3=$ Medicines and vitamins $(\mathrm{ml})$;

X4 = Gas (tube);

$\mathrm{X} 5=$ Husk (sack);

$\mathrm{X} 6=$ Labor $(\mathrm{HOK})$;

$\beta 0=$ intercept or constant;

$\beta i=$ production factor regression coefficient / parameter estimator, where $(i=1,2, . .6)$; vi-ui $=$ error term ( $v i$ is noise effect, $u i$ is the technical inefficiency effect of the model).

Coefficient values expected are: $\beta 1, \beta 2, \beta 3, \beta 4, \beta 5$ and $\beta 6>0$, which means that the results of stochastic frontier production function estimation provide positive estimation value. The coefficient of positive estimation value means to increase input in the form of poultry, feed, medicines and vitamins, gas, chaff, and labor, then it will increase the amount of production of broilers.

Another advantage of the Cobb-Douglas production function is the amount of elasticity of each factor of production that is considered being a business scale estimate or return to scale $(\beta 1+\beta 2+\beta 3+\beta 4+\beta 5+\beta 6)$. If $\Sigma \beta j=1$ means production activity in a constant return to scale (in a fixed business scale). If $\Sigma \beta j>1$ means the production activity in a state of increasing returns to scale (scale effort to increase). If $\Sigma \beta j<1$ means production activity in a state of decreasing return to scale (business scale is declining).

Research Hypothesis:

- It is assumed that broiler breeding business by contract partnership system is more technically efficient when compared to broiler breeder business partnership pattern system for results.

- Allegedly socio-economic factors that affect technical efficiency in the business of broiler farms are: age of farmers, education, and breeding experience.

Technical Efficiency Analysis and Technical Inefficiency Effect. The stochastic frontier approach will result in two simultaneous combinations of factors influencing efficiency and also the inefficiency of breeders. The technical efficiency of each i-th breeders from the output side will be obtained from the observed output of the stochastic frontier output, (Greene, 2005). Analysis of technical efficiency for independent breeders and their respective partners can be measured using the following formula:

$$
T E=\frac{E(Y * \mid U i . X 1, X 2, X 3, X 4, X 5, X 6)}{E(Y * \mid U i=0, X 1, X 2, X 3, X 4, X 5, X 6)}
$$

The value of technical efficiency is between $0 \leq T E \leq 1$. The value of technical efficiency is inversely related to the value of the technical inefficiency effect and is only used for functions that have a certain number of outputs and inputs (cross section data). The technical efficiency value of breeders is categorized as efficient enough if it is $\geq 0.7$ and categorized as inefficient if it is $<0.7$. The $u_{i}$ variable is a random variable that describes the technical inefficiency in production and is related to internal factor; the bigger the value of $u_{i}$, the greater the breeding inefficiency done by the breeders. Random $u_{i}$ variable should not be 
negative and the distribution is half normal with the distribution value of $\mathrm{N}$ (miuiomega3). To determine the value of distribution parameter $\left(u_{i}\right)$, the effect of technical inefficiency of broiler breeding in this study uses the following formula :

$$
u i=\delta 0+\delta 1 Z 1+\delta 2 Z 2+\delta 3 Z 3
$$

Where:

ui = effect of technical inefficiency;

$\delta 0=$ intercept or constant;

$\mathrm{Z1}=$ age of breeder (year);

$\mathrm{Z2}$ = formal education of breeder (year);

Z3 = breeding business experience (year).

The coefficient value of the predictive inefficiency parameter $(\delta)$ is expected $\delta 1>0$, whereas $\delta 2, \delta 3, \delta 4<0$. If the inefficiency predictive parameter is positive then the variable has an effect on the increase of business inefficiency. However, if the inefficiency predictive parameter is negative then the variable decreases the inefficiency of the business or increases the efficiency of the undergone business. In order to be consistent then the estimation of production function parameters and technical inefficiency function are done simultaneously with frontier program 4.1 . The stochastic frontier parameter test and technical inefficiency effect are performed in two stages. The first stage is the estimation of $\beta j$ parameter by using Ordinary Least Squares (OLS) method. The second stage is the estimation of all the $\beta j, \beta 0$, ui and vi variation parameters by using Maximum Likelihood.

\section{RESULTS AND DISCUSSION}

Summary of Broiler Production Function Variable. The function of broiler production using Stochastic Frontier Cobb-Douglass production model in this research is built based on six dependent variables and one independent variable. The independent variables used in the production function of broiler include poultry / DOC $\left(X_{1}\right)$, feed $\left(X_{2}\right)$, medicines and vaccines $\left(X_{3}\right)$, gas / heating $\left(X_{4}\right)$, bran $\left(X_{5}\right)$, and labor $\left(X_{6}\right)$.

Table 1 - Summary of broiler production function estimation data

\begin{tabular}{|c|c|c|c|}
\hline Variables & Mean & Standard Deviation & Coefficient of Variation \\
\hline Production $(\mathrm{kg})$ & 2.925 & 2.928 & 100.08 \\
\hline X1 (DOC) & 2.891 & 1.861 & 64.36 \\
\hline X2 (feed / kg) & 5.401 & 5.141 & 35.20 \\
\hline X3 (Vaccine / ml) & 3.979 & 2.855 & 71.75 \\
\hline X4 (gas / tube) & 24.10 & 15.39 & 63.87 \\
\hline X5 (husk / sack) & 71.2 & 59.7 & 83.93 \\
\hline X6 (labor / HOK) & 37.71 & 28.93 & 76.72 \\
\hline
\end{tabular}

Broiler Production Function Estimation. The estimation of production function with Cobb-Douglass stochastic model is done through two stages. The first stage is done by using Ordinary Least Square (OLS) method and the second stage using Maximum Likelihood Estimation (MLE) method, (Craven and Islam, 2011; Levina and Bickel, 2005). Regression analysis using LS method is intended to obtain the average performance picture of broiler production by breeders at existing technology level, that is, by estimating $\beta$ value. In addition, through the OLS method, the assumption of normality data from the term / error term can be tested using Kolmogorov Smirnov test, multicolinearity test using VIF test, and heteroscedasticity test using graph method. If the three tests are already qualified, the data spread normally, there is no multicolinearity between independent variables and no heteroscedasticity, then it is followed by MLE method.

Estimation result summary of production function parameter with OLS method is presented in table 2. From table 2, it can be explained that not all parameter estimates is positive. It means that any increase in input production will not always have an effect on 
increasing the production of broiler. Table 2 illustrates that there are several variables that significantly affect the production of chicken broiler.

Table 2 - Broiler production function estimation by using OLS method.

\begin{tabular}{|c|c|c|c|}
\hline $\mathrm{n} / \mathrm{n}$ & Coefficient & Standard error & t-Ratio \\
\hline Intercept & 2.039 & 1.117 & 1,743 \\
\hline $\mathrm{X} 1$ (DOC) & 0.458 & 0.237 & 2.929 \\
\hline $\mathrm{X} 2$ (feed / kg) & 0.323 & 0.117 & $\cdot 1.744$ \\
\hline $\mathrm{X}$ (Vaccine / ml) & $\cdot 0.218$ & 0.125 & 0.258 \\
\hline $\mathrm{X} 4$ (gas / tube) & 0.040 & 0.157 & 2.326 \\
\hline $\mathrm{X}$ (husk / sack) & 0.526 & 0.226 & $\cdot 2,159$ \\
\hline
\end{tabular}

Data Normality Assumption Test. The number of samples used in regression analysis of broiler production is 26 samples. To ensure good results analysis, it is required to test the normality of data. Based on the test results, Kolmogorov-Smirnov test on broiler production function of 0.136 . The value of $p$-value obtained in broiler production function is greater than $\alpha=0,05$, so it can be concluded that the research data has fulfilled normal spread assumption.

Multicollinearity Test. Multicollinearity test in this research is conducted by employing VIF (Variance Inflation Factor) test method. If the VIF value exceeds 10, it indicates a multicollinearity problem. The test results show that the VIF value in broiler production function is much greater than 10 , hence it indicates a problem.

Table 3 - Result of multicollinearity test of broiler farm data

\begin{tabular}{|c|c|c|}
\hline No & Free Variables & VIF value \\
\hline 1 & X1 (DOC) & 9.3 \\
\hline 2 & X2 (feed / kg) & 4.2 \\
\hline 3 & X3 (Vaccine / ml) & 7.4 \\
\hline 4 & X4 (gas / tube) & 2.8 \\
\hline 5 & X5 (husk / sack) & 9.7 \\
\hline 6. & X6 (labor / HOK) & 2.8 \\
\hline
\end{tabular}

Heterocedasticity Test. In this research, heteroscedasticity test is done by scatter plot approach between standardized predicted value and standardized residual value. From the figure below, it can be seen spots spread with patterns that tend to cluster.

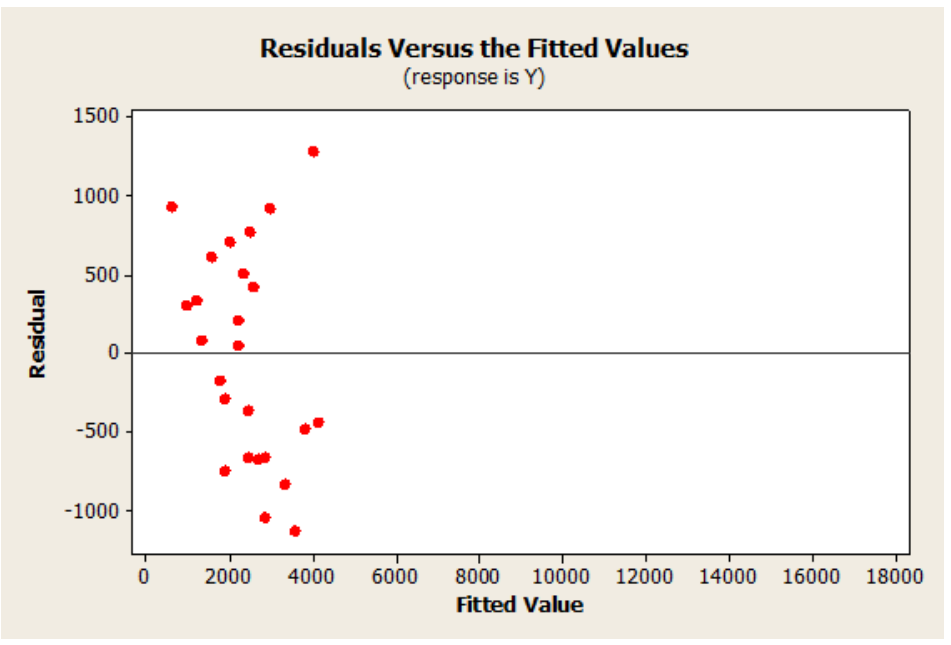

Figure 2 - Result of heteroscedasticity test of broiler breeding

The results of the analysis show that the influence of each factor of production is same as on the OLS method. It can be seen from the t test, in which the most influential factor is 
not the production of poultry $\left(X_{1}\right)$, but it is the husk $\left(X_{5}\right)$ with each positive coefficient $\alpha 1$ percent significance level. While feed (X2), medicines and vitamins (X3), gas (X4), husk (X5) and labor (X6), significantly influence at 5 percent and 10 percent. However, the variable also has a coefficient of positive value. This result is different from research on broiler breeding done by Akhter and Rashid (2008), Ohajianya et al. (2013), and Ezeh et al. (2012) where chicken seed (DOC), feed, medicines and vitamins, as well as labor are influential production factors.

In this study, the results reveal that each factor of production has the same level of elasticity and influence with each other. However, there are two factors, namely medicines, vitamins, and vaccines, and labor are actually inversely proportional. In other words, the addition of these factors actually reduces productivity and decreases the efficiency that will actually reduce production.

Yunus (2009) analyzes the efficiency of the broiler breeding business production in the city of Palu showing variable of feed and poultry production are the factors that most significantly to the positive direction of the production. The value of coefficient of chicken seed variable (DOC) is 0.56 which means every 10 percent of chicken seeds (DOC), it will be followed by a production increase of 5.6 percent, ceteris paribus. Furthermore, Todsadee et al (2012) finds that the number of chicken seeds or DOC have significant effect on a 5 percent with elasticity value of 0.63 on the broiler breeding business in Thailand indicating that every increase of chicken seed or DOC by 10 percent will increase production by 6.3 percent, ceteris paribus.

Based on the result of parameter estimation, feed significantly influences at level of $\alpha$ 10 percent with positive coefficient to production with elasticity value of 0.326 , in which every addition feed of 10 percent, it will increase the number of broiler production by 3.26 percent, ceteris paribus. It is in accordance with research on the factors that affect the production of broiler previously. Burhani (2014) mentions in his research that the feed has a significant effect on the level of a 10 percent with a positive coefficient to the production with a value of elasticity of 0.056 which means that each addition of feed by 10 percent will increase the number of broiler production by 0.56 percent. Prabuwisudawan (2013) in his research explains that the use of feed significantly affects on the production of livestock business with the real level of a 5 percent with the value of elasticity of 0.89 , ceteris paribus. Yunus (2009) in his research also mentions that the feed variable has a real and positive effect on the production with the value of elasticity of 0.41 at the real level of a 1 percent, which means that every increase of feed use by 10 percent will increase the production of 4.1 percent, ceteris paribus. The growth of livestock is determined by the quantity and quality of feed. Growth or weight gain is also an interaction between genetic potential and environmental factor (Mulyantini 2010). If all interact well, then the growth of the livestock keeps going optimal.

Prevention of viruses and diseases should be done by breeders as a form of effort in maintaining the stability of livestock production. When the broiler is attacked or infected with disease, chicken growth will decrease, mortality will increase, which will result in low production. Medicines and vitamins variables are known to negatively related to the number of broiler production in West Java, where the addition of 10 percent of medicines and vitamins will reduce it of 2,85 percent. It is in line with the research conducted by Yunus (2009) stating that the medicines and vitamins correlate negatively and significantly affect broiler production in Palu. It indicates that empirically the use of medicines and vitamins in the business of broiler breeding in the city of Palu has exceeded the dose. However, in the research conducted by Burhani (2014) variables of medicines and vitamins are known to be positively related and have a significant effect on the level of a 20 percent to the production of broiler in Bogor Regency, where the addition of 10 percent of medicines and vitamins will increase production by 0.37 percent.

The next factor that also has an influence on broiler production is gas as a heater. Although in the field, many breeders use other media as heating cages found such as coal and firewood. However, in this study, all breeders are assumed to use gas in order to facilitate the calculation results. Regression results indicate that the gas variable 
significantly influences at a 5 percent with positive signified coefficient of 0.288 . Gas is a heating fuel that is indispensable for the growth of broiler in the cage. Heater with fuel that is generally in the form of gas functions as a temperature regulator of the cage environment. In addition to warming, heating also serves to stimulate the functions of chicken organs, including body temperature control function. The results of this study are in line with Yunus (2009) which states that the use of fuel has a positive effect with the value of elasticity of 0.04 and significant at 5 percent real level. It means that an increase in fuel use by 10 percent will increase production by 0.4 percent, ceteris paribus. The broiler is a warm-blooded animal that still includes animals transitioning from cold-blooded animals to true warm-blooded animals such as mammals. Gasolec with $50 \mathrm{~kg}$ gas fuel can be used up to 16 days old of DOC under normal weather conditions (Christopher and Harianto 2011). The research conducted by Burhani (2014) also mentions that gas variable has a significant effect on the real level of a 15 percent, with positive signified coefficient of 0 , 066.

The factor that is also very influential on the production of broiler is husk. It works from the beginning of chicken care as a bed, as a guard of the temperature stability of the cage, and also as a media of chicken manure absorber. In this study, even the husk holds the highest number as a factor that affects the number of broiler production. Regression results show that the husk variable has a significant effect on the level of $\alpha 15$ percent, with the coefficient signified positive of 0.703 , which means the addition of husk per 10 percent will increase production by 7.03 percent. It is probably because during the research period, the area of West Java, especially for broiler breeders, is suffering from viruses and diseases. There is even one breeder who lost more than half of his chicken due to the outbreak of the virus. It is absolutely a special concern for all concerned parties. For that reason, the husk is one factor that is very influential to the level of the broiler success. According to Fadilah (2004), Mulyantini (2010), Suharno (2012) and Suprijatna et al (2015) the husk that meets the standard is stocked with a thickness of $8-10 \mathrm{~cm}$. Damp husks will increase the level of ammonia coming from chicken manure, which will interfere with health and inhibit the growth of broiler itself. The research of Hapsari (2013) mentions that the husk variable in partner breeders is found to have a positive and tangible effect, while the independent breeder of the husk variable has positive effect but no real effect. It is caused by the use of husks by independent breeders who have not met the existing thickness of husk as a base cage.

The use of labor is important in the production process in any fields. Production works well if it uses enough labor, no shortage or excess, and has sufficient expertise. Based on the results of the analysis, the use of labor in broiler breeding in West Java has not run efficiently. It is found with the result of the number that actually negatively affect the amount of production, with the value of elasticity of -0.257 , which means that every additional labor by 10 percent, it will reduce the amount of broiler production by 2.57 percent, ceteris paribus. The results of this study are not in line with the research done by Prabuwisudawan (2013) and Yunus (2009), which actually provide results that the labor significantly influences the production of broiler. The research conducted by Burhani (2014) also mentions the use of labor in the production process of poultry breeding have a positive effect on the amount of production with a value of elasticity of 0.027 percent that is a 10 percent increase in labor will increase production by 0.27 percent.

The results of the MLE method in Table 4 also illustrate the variance or sigma-squared ( $\Sigma 2)$ and gamma $(\gamma)$ parameters of the technical inefficiency effect model of stochastic frontier production function of broiler breeders and independent breeders. The value of $\Sigma 2$ represents the distribution of technical inefficiency error (ui), where the value is 0.105 . The value is small or close to zero so it is normally distributed. Meanwhile, the obtained value is close to one, that is 0.999 . Therefore, the value indicates that the term error is largely from inefficiency (ui) and only a small amount comes from noise (vi). Whereas if the value of $y$ is near to zero, then most of the error term is as a result of noise (vi), such as weather, climate, pests and diseases, etc., and not the result of inefficiency. If that happens, the inefficiency of coefficient parameter becomes meaningless. This value means that the number of broiler 
production in West Java is influenced by efficiency factor and technical inefficiency of respondent broiler.

Table 4 - Broiler business Stochastic Frontier production function estimation by using MLE method

\begin{tabular}{|c|c|c|}
\hline Variables & Coefficient & t-Ratio \\
\hline Intercept & 572.2 & 1.66 \\
\hline Chicken Seeds/DOC (X1) & 0.2624 & 1.04 \\
\hline Feed (X2) & 0.30593 & 4.98 \\
\hline Medicines and vitamins (X3) & -0.2041 & -1.39 \\
\hline Gas (X4) & -9.60 & -0.58 \\
\hline Chaff (X5) & 37,254 & 4.65 \\
\hline Labor (X6) & -44.237 & -5.00 \\
\hline R & 0.947 & - \\
\hline Adj-R2 & 0.931 & - \\
\hline
\end{tabular}

Technical Efficiency Distribution. Based on the calculation of technical efficiency in table 5 , it shows that in general broiler breeder is only partially efficient in doing business. It is shown from the technical efficiency value which is greater than 0.7 .

Table 5 - Distribution of technical efficiency value of broiler breeding in West Java

\begin{tabular}{|c|c|c|}
\hline Free Variables & Number of Respondents & $\%$ \\
\hline $0.00-0.10$ & 0 & 0.00 \\
\hline $0.11-0.20$ & 0 & 0.00 \\
\hline $0.21-0.30$ & 0 & 0.00 \\
\hline $0.31-0.40$ & 2 & 7.69 \\
\hline $0.41-0.50$ & 6 & 23.08 \\
\hline $0.51-0.60$ & 4 & 15.38 \\
\hline $0.61-0.70$ & 4 & 15.38 \\
\hline $0.71-0.80$ & 4 & 15.38 \\
\hline $0.81-0.90$ & 4 & 15.38 \\
\hline $0.91-1.00$ & 2 & 7.69 \\
\hline TOTAL & 26 & 100 \\
\hline Average Efficiency & 0.64823464 & - \\
\hline Minimum Efficiency & 0.37596114 & - \\
\hline Maximum Efficiency & 0.99989819 & - \\
\hline
\end{tabular}

To increase the productivity of broiler in West Java province, if analyzed through the average value of technical efficiency value, the broiler breeder almost comes into minimum phase efficiency that is at number 0.7. Absolutely, this way can be done by raising awareness of technology and skills in business.

Technical Inefficiency Source. Based on table 6, it is explained that there are two variables from three broiler breeding variables in West Java which have a negative sign. It indicates that it does not significantly affect the production of broiler breeding.

Table 6 - Estimation of the technical inefficiency effect of broiler breeding in West Java

\begin{tabular}{|c|c|c|c|}
\hline Free Variables & Estimation Parameter & Standard Error & $\mathrm{t}$-ratio \\
\hline Age of Breeders & -0.017 & 0.009 & -0.019 \\
\hline Education of Breeders & 0.020 & 0.013 & 0.015 \\
\hline Experience of Breeders & 0.007 & 0.012 & 0.545 \\
\hline
\end{tabular}

\section{CONCLUSION}

The result of analysis by using Stochastic Frontier Cobb-Douglass regression method with the decrease of MLE function shows that some inputs which have real effect to broiler production are seed, feed, and also husk. Moreover, it is also seen that in average, efficiency weight of breeders in West Java is about 0.64 which means it is not efficient yet. It is also the impact of technical inefficiency factor such as age, education level, and breeding experience. 
Based on this research, it still opens big possibility for small breeders to increase the scale of their business in order to get maximum results. One of the ways that can be suggested is to establish a cooperative unit where small-scale breeders can get input with prices that tend to be stable, gain market trust, and increase knowledge and technology about broiler breeding.

\section{REFERENCES}

1. Akhter S, Rashid MHA. 2008. Comparative Efficiency Analysis of Broiler Farming under Aftab Bahumukhi Farm Limited Supervision and Farmers' Own Management. Progress Agriculture, 19 (2): 195-204.

2. Antras, P. (2004). Is the US aggregate production function Cobb-Douglas? New estimates of the elasticity of substitution. Contributions in Macroeconomics, 4(1).

3. Castellini, C., Mugnai, C. A. N. D., \& Dal Bosco, A. (2002). Effect of organic production system on broiler carcass and meat quality. Meat science, 60(3), 219-225.

4. Christopher EJ, Harianto B. 2011. 28 Hari Panen Ayam Broiler. Jakarta: Agromedia Pustaka.

5. Craven, B. D., \& Islam, S. M. (2011). Ordinary least-squares regression (pp. 224-228). Sage Publications.

6. Crowe, S., Cresswell, K., Robertson, A., Huby, G., Avery, A., \& Sheikh, A. (2011). The case study approach. BMC medical research methodology, 11(1), 100.

7. Cullinane, K., Wang, T. F., Song, D. W., \& Ji, P. (2006). The technical efficiency of container ports: comparing data envelopment analysis and stochastic frontier analysis. Transportation Research Part A: Policy and Practice, 40(4), 354-374.

8. Dolton, P., Marcenaro, O. D., \& Navarro, L. (2003). The effective use of student time: a stochastic frontier production function case study. Economics of Education Review, 22(6), 547-560.

9. Ezeh Cl, Anyiro CO, Chukwu JA. 2012. Technical Efficiency in Poultry Broiler Production in Umuahia Capital Territory of Abia State, Nigeria. Greener Journal of Agricultural Sciences. 2(1): 1-7.

10. Fadilah, Roni, et al. 2006. Sukses Beternak Ayam Broiler. Bogor (ID): Agromedia Pustaka.

11. Greene, W. (2005). Reconsidering heterogeneity in panel data estimators of the stochastic frontier model. Journal of econometrics, 126(2), 269-303.

12. Hapsari HW. 2013. Analisis Efisiensi Faktor yang Mempengaruhi Produksi Ayam Ras Pedaging

13. Kumbhakar, S. C., \& Lovell, C. K. (2003). Stochastic frontier analysis. Cambridge university press.

14. Levina, E., \& Bickel, P. J. (2005). Maximum likelihood estimation of intrinsic dimension. In Advances in neural information processing systems (pp. 777-784).

15. Mulyantini. 2010. IImu Manajemen Ternak Unggas. Gadjah Mada University Press, Yogyakarta.

16. Ohajianya DO, Mgbada JU, Onu PN, Enyia CO, Henri-Ukoha AH, Ben-Chendo NG, Godson-Prabuwisudawan D. 2013. Analisis Efisiensi Usaha Ternak Ayam Ras Pedaging Pola Mandiri dan Kemitraan Perusahaan Inti Rakyat di Kecamatan Pamijahan Kabupaten Bogor [skripsi]. Bogor (ID): Institut Pertanian Bogor Produktivitas. Forum Penelitian Agro Ekonomi, 30 (2):109-128.

17. Yunus R. 2009. Analisis Efisiensi Produksi Usaha Peternakan Ayam Ras Pedaging Pola Kemitraan dan Mandiri di Kota Palu Provinsi Sulawesi Tengah [tesis]. Semarang (ID): Universitas Diponegoro.

18. Zhuo, C. H. E. N., \& Shunfeng, S. O. N. G. (2008). Efficiency and technology gap in China's agriculture: A regional meta-frontier analysis. China Economic Review, 19(2), 287-296. 